\title{
An Inquiry About the Roles and Duties of Architects in the Public Sector: Sulaimani Governorate as the Study Field
}

\author{
Saya H. Ahmad, ${ }^{1,}$, Lawen A. Karim¹, Binay O. Rahim¹, Ashkan Azad ${ }^{1}$ \\ ${ }^{1}$ Architectural Engineering Department, Faculty of Engineering, Tishk International University-Sulaimani, Sulaimani, 46001,Iraq \\ *Corresponding Author: Saya H. Ahmad, E-mail: saya.hikmet@gmail.com
}

\begin{tabular}{ll}
\hline Article Info & Abstract \\
\hline Article History & $\begin{array}{l}\text { Architects throughout the time being experienced many roles in different times, while there have } \\
\text { always been unclear what architects underwent and practiced was their actual duty. This research }\end{array}$ \\
Received Jul 25, 2021 & tries to find proper answers about architects' duties, roles, and struggles in the Iraqi Kurdistan \\
Revised Aug 18, 2021 & region. For this reason, questionnaires were applied to ask both the architects and administrative \\
Accepted Aug 24, 2021 & managers in Sulaimani governorate/department of building construction. We find out that the \\
\hline Keywords & main role of an architect in the Sulaimani governorate is mainly designing projects. However, \\
Architect & they are involved in managerial roles as project supervisors destined by the governorate and also \\
Role of architect & another role of the architect is checking the drawings of the projects designed outside of this \\
Public sector & administration office. Another finding was that the architects in Sulaimani governorate or Iraqi \\
Sulaimani governorate & Kurdistan region generally face the problem of that their works are done by other specialists, \\
& which sometimes cause some domain faults in the works and do not have enough or proper area \\
& to work in.
\end{tabular}

Copyright: (C) 2021 EngiSciece Publisher All rights reserved

\section{Introduction}

Architects create designs for new construction projects, alterations and redevelopments. They use their specialist construction knowledge and high-level drawing skills to design functional, safe, sustainable, and aesthetically pleasing buildings. He/she is mostly the guidance or leader of the designing and construction team, whose clients are related to his/her ideas directly [1].

Moreover, an educated and licensed professional who plans, designs, and supervises the building of structures and spaces, whose responsibilities may differ based on the project types. However, they are usually entrusted with overseeing the whole project tasks [2].

Nowadays, architects work in different roles and in different places such as in municipalities, architectural offices, private organizations, governorates, universities, to name a few. Thus, when this research targeted the roles of architects in the Sulaimani governorate, first, it is necessary to know what is governorate and its capacity.

A governorate is a country's official organization. It is presided over by a governor. Because territories governed by governors are commonly referred to as states, districts, or colonies in English-speaking countries, 
the word governorate is frequently employed in translation from non-English-speaking administrations. The most prevalent application is as an English translation of the Arabic Muhafazah [3].

Governorates are responsible for providing services that individuals cannot effectively provide for themselves, such as roads, education, social services, and environmental protection. Another responsibility is the protection of cultural heritage, both tangible and non-tangible is a national service. For this purpose, funds are allocated in the annual governorate budgets at the federal and provincial levels. Some governorate entities also provide public utilities, such as water, sewerage treatment, or electricity. To generate the revenue necessary to provide services, governorates collect taxes and fees and charge for many services they provide to the public [4].

For these city-related services, governorates need an active engineering/building construction/consultancy department. In this department having architects is inevitable. The governorate architects provide strategic design leadership in architecture, urban design and landscape architecture. However, what is going on nowadays, and more specifically in Sulaimani governorate's building construction department, is confusing regarding the architects' roles and duties in this administrative body. This study aims to ascertain what exactly architects do there and is what they expected to do. Moreover, there is no research about the architect's role in governorates of the Iraqi Kurdistan region.

The research project starts with studying the architects' role in general that has been found in the current literature. Then, delving into the roles and duties of architects in Sulaimani governorate through questionnaires and interviews. This paper provides information for recently architecture graduates and architecture students to have enough knowledge concerning their future duties in different sectors they would work in.

\section{Materials and Methods}

The 'architect' was the person who could build structures that did not fall down. In fact, the word architect comes from the Greek word for 'chief carpenter,' architektōn [5]. Architecture was not always thought of as a profession.

In the United States, architecture as a licensed profession changed in 1857. Before the 1800s, any talented and skilled person could become an architect through reading, apprenticeship, self-study, and the current ruling class [6]. Ancient Greek and Roman rulers picked out the engineers whose work would make them look good and add to their prosperity in designing better spaces [7]. The great Gothic cathedrals in Europe were built by masons, carpenters, and other artisans and tradespeople. Over time, wealthy, educated aristocrats became key designers. They achieved their training informally, without established guidelines or standards[8].

Contemporary architecture is a form of construction that embodies the various styles of building designs stemming from a wide range of influences [9]. Furthermore, several of the most prominent contemporary architects, including Norman Foster, Santiago Calatrava, Zaha Hadid, Le Corbusier, Philip Johnson, do design 
in so many different ways and architectural styles and philosophies that differ from architects of the classic era. Architects of the modern time pay less attention to decoration and complexity in their designs and make clearer and simpler designs. They used different materials like glass, steel, concrete, etc.

Furthermore, modern architecture is mostly toward environmentally friendly and sustainable design. Sustainable architecture seeks to minimize the negative environmental impact of buildings by efficiency and moderation in the use of materials, energy, and development space and the ecosystem at large [10]. Contemporary architecture cuts away from the modern architecture of the late twentieth century by including ecofriendly features and embracing all kinds of creativities that today's people needs [11].

Back in the Middle Ages in Europe, architects, due to that era's economic and challenging conditions, were in the role of masons, skilled mason builders. While in the time of Renaissance, when Europe witnessed revive in all aspects of life, architects work attracts more attention. They progressed their artistic side and started to design buildings to give people a higher sense of taste. So, architects can be seen as facilitators between general political, social, and economic conditions and people's needs and values. What is clear from the previous discussions is that architects have been acted according to every era's needs and requirements. That is why their roles and responsibilities are unlikely similar.

Nowadays, due to the globalization and rapid-paced world of technology, the role and responsibilities of architects recorded a milestone of confusion, as the profession of architecture faced many divisions and sub-professions like interior design, lighting, sound, landscape design etc. that are all separated from the body of the architecture profession. That is why a clear pathway of what should architects do or not do is not apparent.

\section{Methods}

A field study has been chosen for data collection, the Sulaimani governorate/building construction department. This department consists of five sectors regarding the necessities and types of activities, while architects work in all sectors. The researchers had the opportunity to collect data from the architects working in these sectors. As the tool of the data collection, questionnaires were applied and filled directly from their responses. It contained a set of purposeful questions that follow a fixed scheme to collect individual data about one or more specific topics. Questions asked were mostly about what you do in this department, your duty and responsibility, are you satisfied with what you do, and questions alike. The questionnaire method was chosen because of its: less expensive, quick results, less opportunity for bias and errors, wide-coverage, respondents may use personal records, collection of data about sensitive topics, less time consumption and high response rate. 


\section{Results and Discussions}

The data collection procedure targeted both administrative managers as well as architects in this department. Then in the eye of both sides, the roles and responsibilities of architects are explained:

\section{- Administrative managers:}

They declared that five architects are working there; two females and three males. Four of them have bachelor's degrees and one master degree. They mentioned that their architects are in several roles as design, working office duties, programming, construction supervisions and several other duties as checking measurement and payment calculations. However, they are more talented in programming, especially those programs that are more towards renderings and design-related programs.

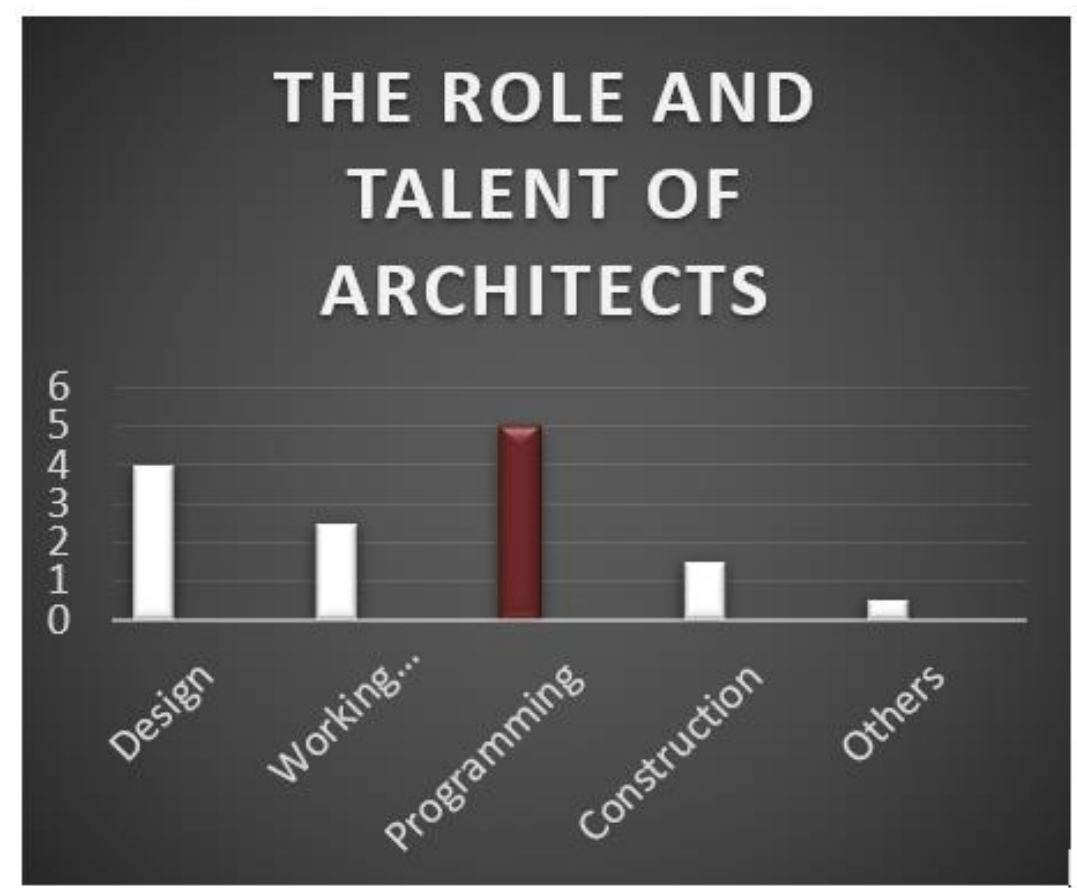

Figure 1. The role and talent of architects in the eye of the administrative managers in Sulaimani governorate

\section{- Architects:}

This part question was asked to the architects themselves, and the questions were subdivided into several parts, including general, role, and duty-related questions.

\section{General:}

To answer the question of which duty an architect should perform, the majority of the architects chose both design and solving problems. Moreover, decision-making took second place. The architects extended their discussions regarding the questions were asked, and themes arranged as such:

Communicability helps the architect during his work in governorate: 


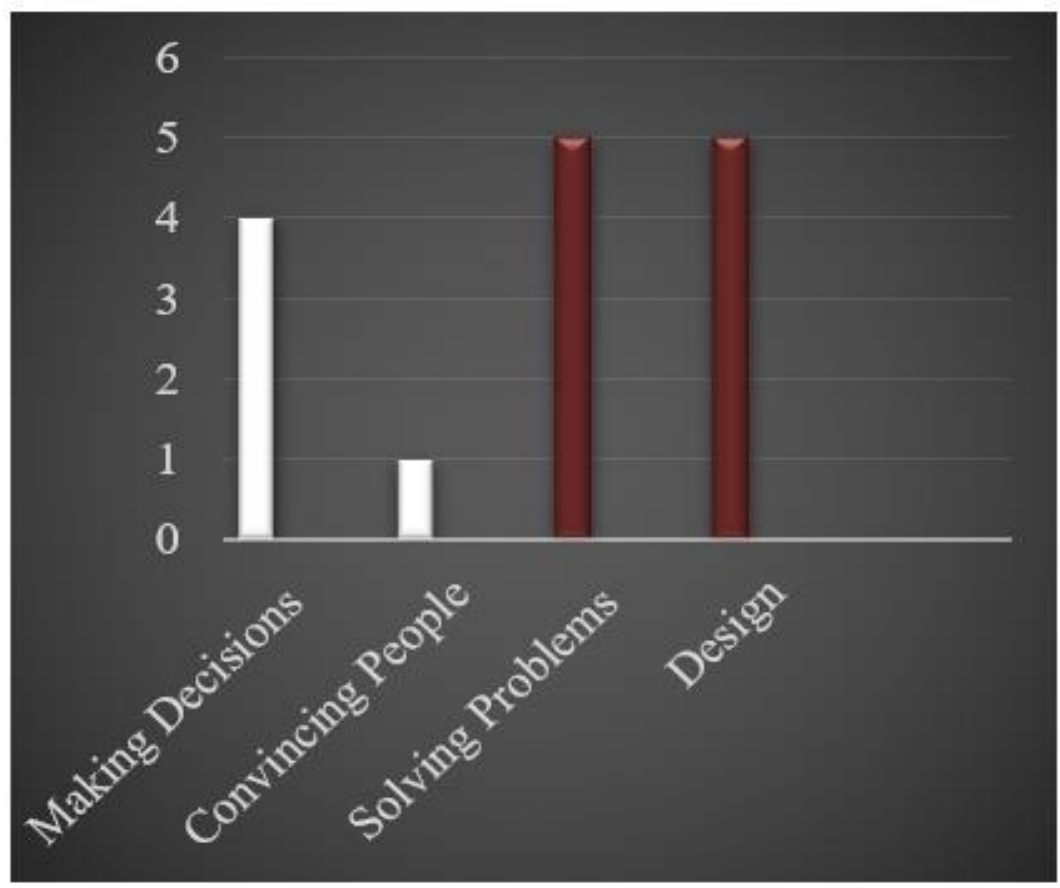

Figure 2. The roles and duties architects involved in

They believe that because of the decision made before, and most of the cases they have the opportunity to just check the designs done outside by architectural offices, there is no communication between the architect and the client in this administration. Sometimes architect may change his/her decision after making communication with others. By communicating, they will understand better and learn more about the project. We do not have such a chance because, in the public sector, architects do not need the ability to convince people, but in the private sector, they need it.

The problems in the governorate for architects are:

Architects do not have their own space where they can work until now. They change architect's decisions and works every so often. Sometimes, other professions will do works instead of architects that are not their job or do not do exactly what the architect had told them. Architects need a special place to work in. In the construction of the project, architects have less authority compared to other specialties.

\section{Role:}

What is the role of an architectural engineer?

Generally, they are satisfied with their daily works. There is no clear program, specifically for architects, to outline your duties and responsibilities. Architects work is different from what civil engineers do there.

What does differentiate architects from other specialists? 
In answering this question, they thought design and programming in architecture, the ability to make decisions, and consideration of the tradition and culture during design are the most important points that distinguish architects from other professionals. Moreover, architects are those who involve in the pre-design and programming stages.

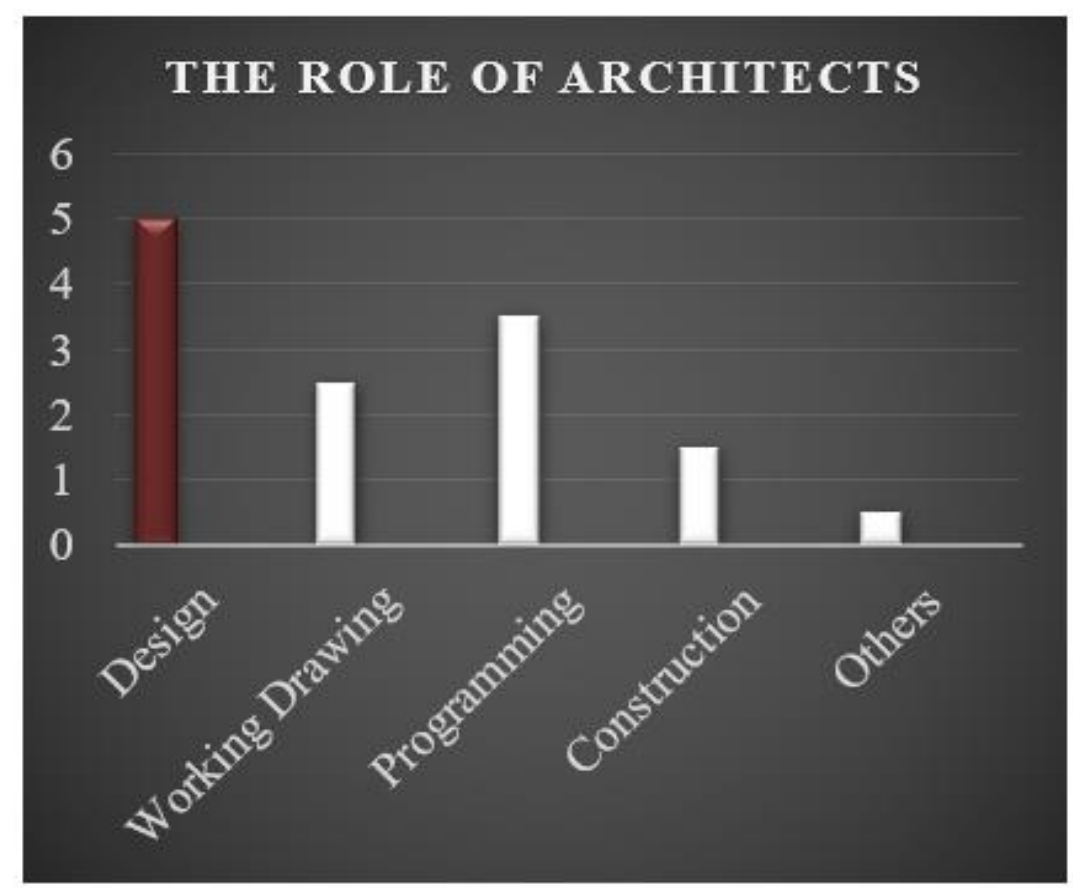

Figure 3. The role of architects in different duties

What are Architects dream jobs?

According to their responses, design and supervision, programming, making working drawing for a big project, redesigning the historical districts of Sulaimani are the most preferred jobs if they have the chance to practice it.

Do you like teamwork and collaborative working?

They all agreed with working collaboratively in teams with other professionals. Because of some advantages which are:

Avoiding the mistakes and completing the project in the expected time, and having different ideas for solving the problems. Moreover, finding appropriate solutions for the problem more effortlessly.

What is the architects' role in design decision and their impact on constructability?

Always architects are expected to be the design head they designed. In each step of construction, the construction staff should return to the architect's decision. The construction process should be according to the architect's decision, but unfortunately, it is not like that. Architects are responsible for managing the projects they designed. Architects do not play the main role in the governorate. The broad and deep technical 
knowledge mostly does not affect a better role of architects working here in the governorate. Regarding the duties, duties change according to the different sectors: design, programming, and supervising the projects they designed, visiting sites, designing and doing new projects or rehabilitating old buildings.

\section{When do Architects review projects in governorate more?}

They answered; when the drawings do not match with the construction on the site. Moreover, when there is an unexpected problem on the site. Sometimes some changes are done after starting the construction. When a problem occurs, if a problem occurs, they will fix it.

\section{Which duties are more challenging to you?}

Programming, because other peoples are not familiar with this field, so they cannot do it. More attention should be taken to programming as it is the most important duty of architects, but it does not here, unfortunately, because sometimes all other professions are also doing it even, they do not know how to manage it. Not assigning duties of professions is very complicated. Someone is doing another one's job, and another one is not doing their job. Sometimes the design of other typical projects in other places (Erbil) is used, so it will not be suitable for the project's site.

Architects in the governorate sometimes are not listened to: for instance, and they make decisions that others told them not to do. While later will do the same thing by themselves because they know architects' decision was true, they take the credit for themselves. Another thing, in construction, most of the responsibilities are given to the civil engineers.

According to the process of designing the construction of any project, there are different sectors in the Sulaimani governorate. First, when the governorate requests architects to do a new project in the city, they will propose the project's design to the 'design sector'. This sector should do its duty; designing projects. However, they do not design, maybe not let them do it; rather, the decision-makers give it to an exterior agent, an architectural design office.

The situation for the construction sector in this department is different; they are responsible for taking care of the projects that are under construction, they do supervise the design and construction of the projects.

First, the main role of the architect in the governorate is doing design. Another architect's role is to prepare the drawings and tender for the projects they designed, or sometimes they have got the design from other designers outside. After that, another role of the architect in the governorate is management. Every project should have an architect as a manager to lead all other engineers in other specialities like civil, electrical, mechanical, etc., because their decision and works will affect the design of the project, so it should be under the guidance of the architects. Programming is another important duty of architects that they should 
make space programming for the projects, considering some important factors like (function, form, time, economy, environment, urban context, history and tradition).

In the Sulaimani governorate, architects challenge programming because it is the field that other specialists cannot do except architects, which is why they cannot collaborate. After the study results regarding the architects' roles and challenges in the governorate of Sulaimani, we came to some conclusive points:

Negative Points:

- Architects do not have enough authority in managing projects sometimes; other specialists change their decisions or may not apply them.

- Most of the projects have typical design and design procedures, so there is less opportunity of making challenges and creativity.

Positive Points:

- The ability to convince the architects in governorate is not as important as its for private sectors because their project is for the general sector or they do not meet clients directly.

- In a governorate, the architects should work in a team to find a suitable solution for the problems.

- There is no difference between female and male architects there.

- Architects in the governorate are most talented in designing.

- According to their sectors, they have different duties and responsibilities, such as designing, programming, working, drawing, review or check-up for the projects.

\section{Conclusions}

There is confusion in the current duties and responsibilities of architects. For that purpose, this study has been conducted to unveil architects' roles in the public sector. For that reason, the Sulaimani governorate/building construction department has been taken as a study field. Architects are positioned in some sectors in this department either it is not their duty or cannot collaborate with their other fellow colleagues as civil, electrical, and mechanical engineers. One of these subjects is programming. In programming, architects can manage the process while others are not as familiar as architects to collaborate better together. While the main duty of architects is doing design, due to their profession's nature, architects are less involved in design activities. Instead, they check drawings for the projects that have been done by exterior agents, architectural offices for the Sulaimani governorate. This causes the architect not to have the chance to be involved with the clients as they have to be. The study recommends that the Sulaimani governorate place architects in the sectors 
that can directly involve and deal with design. Instead of hiring the architectural offices to design and prepare architectural sets, they can use their own architects.

Declaration of Competing Interest The authors declare that they have no known competing of interest.

\section{References}

[1] C. M. Eastman, Building product models: computer environments supporting design and construction. CRC press, 2018.

[2] D. Cuff, Architecture: The story of practice. Mit Press, 1992.

[3] URL-1, "Governorate," in Definitions, ed, 2021.

[4] A.-M. Massadeh, "A Comparison of Jordanian Governorate Councils and Local Government Councils: Constitutional Perspectives and Legal Implications," Arab LQ, vol. 7, p. 99, 1992.

[5] A. Stewart, "Patronage, Compensation, and the Social Status of Sculptors," in Volume 1 Handbook of Greek Sculpture: De Gruyter, 2019, pp. 50-88.

[6] P. H. Thornton, C. Jones, and K. Kury, "Institutional logics and institutional change in organizations: Transformation in accounting, architecture, and publishing," in Transformation in cultural industries: Emerald Group Publishing Limited, 2005.

[7] L. S. De Camp, The ancient engineers. Barnes \& Noble Publishing, 1990.

[8] J. Harland-Jacobs, Builders of Empire: Freemasons and British Imperialism, 1717-1927. Univ of North Carolina Press, 2007.

[9] S. R. Kellert, Nature by design. Yale University Press, 2018.

[10] A. A. Othman, "Sustainable Architecture: an Investigation into the architect's Social Responsibility," in International Conference on Sustainable Human Settlements for Economic \& Social Development, 2007.

[11] M. M. Kolakowski, "Low-Tech-Freedom, Creativity \& Love. Translating Erich Fromm's Psychoanalysis into Analyses of Architecture," UOU scientific journal, no. 01, 2021. 